\title{
Pricing Decisions in International Industrial Markets - The Link between Standardization at Market Entry, Pricing Capability, and Price Reactions
}

\author{
Susanne Kreiter ${ }^{1} \&$ Roland Helm ${ }^{1}$ \\ ${ }^{1}$ University of Regensburg, Chair of Strategic Industrial Marketing, Universitätsstraße 31, 93053 Regensburg, Germany \\ ${ }^{1}$ Correspondence: Susanne Kreiter, University of Regensburg, Chair of Strategic Industrial Marketing, \\ Universitätsstraße 31, 93053 Regensburg, Germany.
}

Received: June 11, 2018

Accepted: July 20, 2018

Online Published: July 26, 2018

doi:10.11114/bms.v4i3.3486

URL: https://doi.org/10.11114/bms.v4i3.3486

\begin{abstract}
International pricing decisions are one of the most paramount decisions managers face. By linking international marketing and competitive dynamics this paper reveals a relationship between product and price standardization at international market entry and defensive price reactions after market entry based on the concept of path dependencies. The empirical evaluation of a structural model shows that standardization positively influences slack resources after adaptation decision and in addition price formation capabilities. In line with the awareness-motivation-capability framework our results show a negative impact of price adaptive capabilities on price reaction.
\end{abstract}

Keywords: international pricing, standardization, adaptation, pricing capability, price reaction, industrial goods, emerging markets

\section{Introduction}

Nowadays, international market entry decisions are one of the most paramount decisions marketing managers face (e.g. Anderson and Gatignon, 1986; Brouthers, 2013; Kogut and Singh, 1988; Sarkar and Cavusgil, 1996). Moreover, increasing competition worldwide has made marketing decisions ever more important to the survival, growth and profitability of firms (Douglas and Craig, 2011; Katsikeas, Samiee, Theodosiou, 2006). When facing a high level of competition, firms have to be market-oriented regarding monitoring competitors, developing their own competitive strategies in line with anticipating and responding to competitors' actions (Gatignon and Xuereb, 1997; Murray, Gao and Kotabe, 2011) to be successful. Thus, international marketing managers need guidelines on how to respond to competitive actions they face in export markets.

According to the research of competitive dynamics (Smith, Ferrier and Ndofor, 2001) quick and thoughtful reactions on competitive moves can be explained according to the awareness-motivation-capability (amc) framework (Chen, 1996; Smith, Ferrier and Ndofor, 2001). They are influenced by path dependencies (Hutzschenreuter and Israel, 2009) which indicate that pre-set strategies depose constraints in subsequent strategic decisions (Sydow, Schreyögg and Koch, 2009). Thus, competitive reactions can be influenced by former market entry decisions (Karakaya and Yannopoulos, 2010).

Within international marketing the issue of standardization vs. adaptation is among the most relevant decisions at market entry (Douglas and Craig, 1989) and refers to the degree to which the marketing-mix strategies for the main exported products differ from the domestic market as compared to the main foreign market (Jain, 1989; Sorenson and Wiechmann, 1975). Despite its influence on a firm's overall internationalization strategy and structure (Douglas and Craig, 1989; Schmid and Kotulla, 2011) the vast majority of research has examined several antecedents and consequences of international marketing standardization and adaptation (Schmid and Kotulla, 2011; Tan and Sousa, 2013) without considering its evolutionary character (Douglas and Craig, 1989). Furthermore, academic research in this field lacks theoretical foundation (Birnik and Bowman, 2007; Helm and Gritsch, 2014; Ryans, Griffith, White, 2003; Schmid and Kotulla, 2011; Theodosiou and Leonidou, 2003; Tan and Sousa, 2013). In line with that Tan and Sousa (2013) doubt that international marketing strategy achieve results from completely unconstrained choices and suggest looking at marketing standardization issues from the perspective of the concept of path dependencies. Thus, standardization issues should be regarded in combination with subsequent marketing decisions.

A small fragment of hitherto empirical findings can be linked to this perspective (e.g. Albaum and Tse, 2001; Cavusgil, Zou and Naidu, 1993; Özsomer and Prussia, 2000; Özsomer and Simonin, 2004; Sousa and Bradley, 2009; Swoboda 
and Elsner, 2013; Timmor and Zif, 2005). However, they do not provide answers on how to meet local competition with marketing strategies and be successful with the responsiveness to local market conditions. As a consequence, the aim of this study is to depart from the marketing-mix decision of standardization vs. adaptation made at initial foreign entry and predict influences on marketing-mix decisions made after market entry which are aimed at meeting host-market competition. The fact that the standardization issue is considered as one fragment of a firm's market entry decision is expressed by the term " $\mathrm{t}_{0}$ " Hence, in this paper the issue of standardization vs. adaptation at market entry is taken as given and the two research streams of international marketing and competitive dynamics are linked.

We focus on international pricing decisions because they are largely neglected in international marketing literature (Skarmeas et al., 2014; Sousa and Bradley, 2009; Tan and Sousa, 2011) as well as in competitive dynamic literature, although price is one of the most widely used competitive weapons, also within industrial markets (Kuester, Homburg and Robertson, 1999; Ramaswamy, Gatignon and Reibstein, 1994). Furthermore, despite the fact that pricing capability should be central to every managerial decision regarding pricing (Dutta, Zbaracki and Bergen, 2003) a research gap exists concerning the identification of antecedents of pricing capabilities (Liozu and Hinterhuber, 2013) especially in the context of exporting (Skarmeas et al., 2014).

To the best of our knowledge, we are the first who conduct an empirical investigation of competitive marketing behavior in industrial markets corresponding to international pricing decisions after market entry in dependence on international standardization at market entry. The theoretical contribution of this paper is threefold:

1. We extend the marketing standardization vs. adaptation debate by referring to its evolutionary character and linking it to path dependencies which contributes to diminish the lack of its theoretical embeddedness in international marketing literature (Schmid and Kotulla, 2011, Tan and Sousa, 2013).

2. We extend the competitive dynamics research by examining whether a price reaction should be employed after international market entry on the basis of the amc-framework.

3. We shed light on the interdependency of international pricing decisions, answering the call for capturing changes and dynamics of international pricing strategies by Tan and Sousa (2011).

Therefore, the managerial contributions are twofold.

We show managers that decision making within international industrial competitive environments is an interconnected process, insofar as standardization vs. adaptation issues at market entry have an effect on pricing decisions after market entry, and we sensitize managers to think in a more long-term way about market entry decisions. The findings can be used for competitive intelligence purposes, too.

\section{Theoretical Foundation}

\subsection{International Standardization vs. Adaptation and Path Dependencies}

Marketing-mix standardization issues are highly relevant due to their potential to enhance business performance (e.g. Cavusgil and Zuo, 1994; Shoham, 1999; Samiee and Roth, 1992), their influence on a firm's overall internationalization strategy and structure (Douglas and Craig, 1989; Schmid and Kotulla, 2011) and their influence on allocation issues which can be a source of resource heterogeneity among firms (Cavusgil and Zou, 1994; Dow, 2006; Shoham, 1999). Although industrial products are more likely to be standardized (Jain, 1989; Samiee and Roth, 1992; Schilke, Reinmann, and Thomas, 2009), they should be examined in consideration with further marketing-mix instruments (Kustin, 2004). But instead of considering the whole marketing-mix we focus on product and pricing standardization because the question of pricing is closely related to the product strategy of a company (Helm and Gritsch, 2014) although a product standardization not necessarily results in a price standardization (Sousa and Lengler, 2009). Additionally, the relevance of pricing standardization in industrial marketing settings was already empirically confirmed by Helm and Gritsch (2014). The vast majority of research regarding marketing standardization issues concentrates on the identification of antecedents regarding the choice between international marketing standardization and adaptation or identifies its performance potential (Schmid and Kotulla, 2011; Tan and Sousa, 2013; Theodosiou and Leonidou, 2003). So far only little research takes a different perspective and draws a relationship to other marketing-mix related issues like centralization (e.g. Özsomer and Prussia, 2000; Özsomer and Simonin, 2004), pre- and post-entry decisions (Albaum and Tse, 2001; Cavusgil, Zou and Naidu, 1993) or the mutual influence of the marketing-mix instruments (e.g. Sousa and Bradley, 2009; Swoboda and Elsner, 2013; Timmor and Zif, 2005). Thus the evolutionary character of marketing-mix standardization issues (Douglas and Craig, 1989) is mostly ignored. Besides the narrow research focus, most of the recommendations lack a theoretical basis (e.g. Birnik and Bowman, 2007; Ryans, Griffith and White, 2003; Theodosiou and Leonidou, 2003).

According to the path dependence theory, the history always matters and the sequence of events is essential in explaining social outcomes (Pierson, 2000). However, Sydow, Schreyögg and Koch (2008) claim that organization 
research uses path dependencies as a broad label indicating all kinds of imprinting effects of the past on organizational behavior (e.g. Beckman and Burton, 2008). Additionally, the authors state that these dependencies include more than the mere existence of timeworn routines, cognitive rigidities, or structural inertia. Already Tan and Sousa (2013) transfer this concept to the international marketing mix context and suggest that international standardization decisions should be regarded as a result of constrained rather than unconstrained choices.

\subsection{Competitive Dynamics: Price Reaction Based on the Awareness-Motivation-Capability Framework}

Competitive actions and responses are explained by competitive dynamic research (Chen, 1996; Smith, Ferrier and Ndofor, 2001). Although price is one of the most widely used competitive weapons of the marketing mix, also within industrial markets (Kuester, Homburg and Robertson, 1999; Ramaswamy, Gatignon and Reibstein, 1994) nothing is known about changes in international pricing as a reaction to competitive actions.

If a firm wants to change its pricing, effects can be double-edged. On the one hand, price reactions are of crucial importance to the success of a firm because they have a direct effect on revenues (Rao, 1984; Sousa and Bradley, 2009; Tan and Sousa, 2011). Moreover, they are implemented quickly, thus can avoid losing customers' to competitors (Kuester, Homburg and Robertson, 1999) and be an effective mean to defend current and future market potential (Robinson, 1988; Bowman and Gatignon, 1995; Debruyne, Moenaert, Griffin, Hart, Hultnik and Robben, 2002). On the other hand, price reactions can lead to counter reactions culminating in ruinous price wars (Heil and Helsen, 2001; Simon, 2005) due to being highly visible to competitors (Rao, 1984) and affecting their profitability (Kuester, Homburg and Robertson, 1999). Furthermore, they have a marked effect on margins (Ramaswamy, Gatignon and Reibstein, 1994) and can be causative for the creation of unrealistic reference prices of customers which hinder future price increases (Heil and Helsen, 2001). Thus price reactions are a key determinant of performance and can have positive as well as negative effects on it.

Based on the awareness-motivation-capability framework researchers identify resources and capabilities as key instruments for firms to defend themselves against competitive attacks and respond to competitive moves (Debruyne, Frambach and Moenaert, 2010). According to the amc-framework there exist "three drivers of interfirm rivalry" (Chen, Su and Tsai 2007: 101); namely, the awareness of the attack, a firm's motivation, and its capability to respond. Transferred to international contexts, the amc-framework implies that firms will respond to a rival's action to the extent that they are 1. aware of the action in the host country 2. motivated to respond to the action 3. capable of deploying resources for responding in the host country (Yu and Cannella, 2007).

First, the firm must be aware of the attack, meaning that competitive moves must be sufficiently large and generate signals that are noticeable to incumbents (Smith and Grimm, 1991; Chen, Smith and Grimm, 1992). Theoretically the aspect of awareness is related to the organizational communication perspective, which describes that competitive actions are the result of the decision-making process of information-seeking and information-processing activity (Smith and Grimm, 1991; Smith, Grimm and Gannon, 1992; Helm, Krinner and Schmalfuss, 2014).

The second driver of the likelihood of a competitive attack is the motivation of actors to attack or defend (Chen, Smith and Grimm, 1992; Ferrier, 2001). It is grounded on expectancy-valence theory (Vroom, 1964) arguing that the subjective reward value (valence) of acting effectively and the expectation or perceived probability of earning the reward (expectancy) are two basic conditions that underlie the tendency to act.

Third, the capability of actors to attack or to defend depends b.o. on their resource endowments which is grounded on the resource-based view of the firm (Barney, 1986; Dierickx and Cool, 1989; Peteraf, 1993). In this paper, we concentrate on financial slack resources, thus high-discretion slack, because scholars have shown that financial slack influences managerial decision making (Singh, 1986). In addition, it creates leeway to react to competitive actions (Debruyne, Frambach and Moenaert, 2010), thus provides firms with flexibility in dealing with competitive events and can readily be deployed to adapt to unforeseen developments (Mishina, Pollock and Porac, 2004; Nohria and Gulati, 1996). Due to the fact that we consider international pricing behavior, we focus on pricing capabilities of a firm because they are central to any pricing decision (Dutta, Zbaracki and Bergen, 2003) and constitute the essential capability for firm survival (Dutta et al., 2002). Pricing capabilities are defined here as a set of complex routines, skills, systems, know-how, coordination mechanisms and complementary resources used to do an effective job of pricing (Dutta, Zbaracki and Bergen, 2003; Liozu and Hinterhuber, 2014). Due to its complexity (Liozu and Hinterhuber, 2014) we distinguish between price adaptive capabilities and price formation capabilities. The former refers to the capability to respond quickly to competitors' actions and customer changes in terms of price adjustments (Liozu and Hinterhuber, 2014; Murray, Gao and Kotabe, 2011). Price formation capabilities comprise all activities regarding the optimal intra-company price formation, the knowledge of competitors' tactics, the communication of price changes to customers as well as the monitoring of competitors' prices (Dutta, Zbaracki and Bergen, 2003; Vorhies and Morgan, 2005). Despite their importance for the development of sustainable competitive advantages only little is known about 
antecedents and implications of pricing capabilities (Dutta, Zbaracki and Bergen, 2003; Liozu and Hinterhuber, 2013; Skarmeas et al., 2014).

A price reaction is defined here as the degree to which the pricing (determination of list prices and price discount policies) is changed by the firm after market entry in relation to the point of market entry. This aspect is highlighted by " $t_{1}$ " in the following analysis. Similarly, a missing price reaction implies that the pricing did not change initially after entry. In the context of international pricing strategies for industrial markets such price reactions have not been regarded at all so far. In relation to that and the awareness-capability-framework pricing strategies in this paper are defined as defensive in nature.

Figure 1 summarizes the key relationships between standardization vs. adaptation issues and price reactions drawn in this paper.

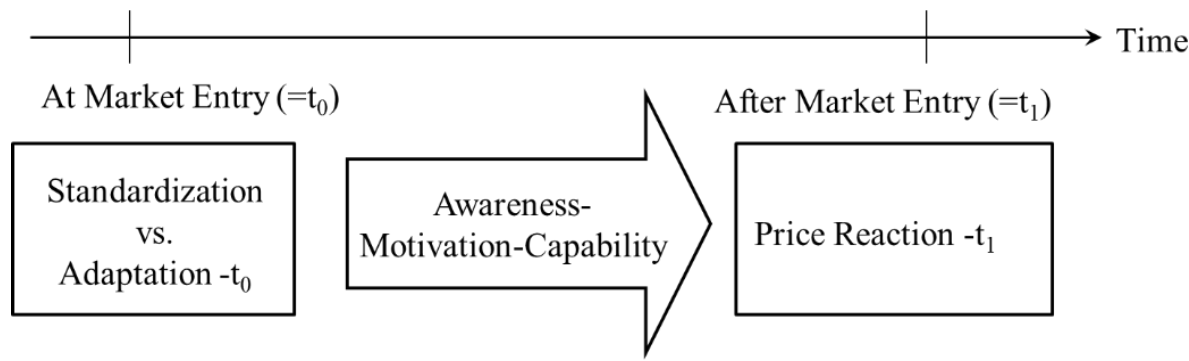

Figure 1. Relationships Framework between standardization and price reaction

\section{Hypotheses}

On the one hand, reduced costs of adaptation and the ease of administering standardized marketing programs make this strategy an attractive choice for firms (Douglas and Wind, 1987; Dow, 2006; Shoham, 1999). On the other hand, literature demonstrates that adaptation enables a company to adjust its strategies according to local competitive conditions and customer needs, thus enhancing its ability to position itself in the market (Albaum and Tse, 2001; Kirpalani and Macintosh, 1980). With the implementation of a standardized marketing strategy fewer resources are allocated to the international market in comparison to the implementation of an adaptation strategy. Thus, one benefit of the standardization strategy is the lower amount of costs that is associated with it (Jain, 1989; Lages, Abrantes and Lages, 2008; Shoham, 1999; Wind, 1986) which can also be the result of economies of scale and scope (Levitt, 1983; Sorenson and Wiechmann, 1975).

The resources dedicated to adaptation enable a company to adjust its strategies according to local competitive conditions and customer needs, thus enhance its ability to position itself in the market (Albaum and Tse, 2001; Kirpalani and Macintosh, 1980). The allocation of financial and management related resources is part of the planning process of market entry strategies (Cavusgil and Zou, 1994). Therefore, we assume that the implementation of a standardized vs. an adapted marketing-mix strategy is a conscious decision against vs. for higher costs, associated with an adaptation strategy and hence results in resource differences between firms. Financial resources that are consciously not allocated and stored for future activities become part of slack resources (Donada and Dostaler, 2005) and might be stored as planned buffer (Voss, Sirdeshmukh and Voss, 2008).

Here, we examine slack resources after adaptation as the quantity of (financial) resources which was not needed for the implementation of pricing and product adaptation at market entry. Taken the statements above together, we suppose that:

Hypothesis 1. The more standardized the pricing and product decisions at market entry $\left(t_{0}\right)$, the higher the level of slack resources after adaptation decision.

According to the capability-based perspective, resources nurture firm capabilities and a firm's ability to deploy resources through organizational capabilities is more critical to competitive advantage than resources themselves (Amit and Schoemaker, 1993; Day, 1994; Dierickx and Cool, 1989; Eisenhardt and Martin, 2000). Moreover, resource deployment in firm capabilities is critical (Dierickx and Cool, 1989; Slotegraaf, Moorman and Inman, 2003). Slack resources can be invested for the development of capabilities (Christenson, 1973; Miles and Cameron, 1982) and allow international marketing managers to improve a firm's further adaptive capabilities for coping with other changes in the international business environment (Chang, 1995), like e.g. capabilities for the acquisition of critical export market information (Kaleka, 2011). Due to the fact that the development of pricing capabilities requires resource investments (Dutta et al., 2002) we think that financial slack resources can enhance these pricing capabilities in the following way: 
First, slack resources act as environmental buffer (Thompson, 1967), which give firms a security regarding unexpected future developments (Kraatz and Zajack, 2001). In line with that, Denison, Dutton, Kahn and Hart (1996) argue that the higher the level of financial resources, the more the firm feels able to cope with external factors. Besides the positive influence of slack resources, literature arguments that slack is beneficial for a firm only to a certain extant (Bourgeois, 1981; Nohria and Gulati, 1996; Tan and Peng, 2003) because it can be causative for inefficient behavior (Slotegraaf, Moorman and Inman, 2003) like inertia (Daniel, Lohrke, Fornaciari and Turner, 2004) which inhibits the ability to adjust to uncertainty and adapt to environmental changes (Hannan and Freeman, 1984). However, in our context we suppose a capability enhancing effect of slack resources tying in with Oktemgil and Greenley (1997) who found empirically a positive relationship between slack resources and adaptive capability as well as with Debruyne, Frambach and Moenaert (2010) who showed that financial resources positively influence the perceived ability to react to a competitor's moves. Kaleka (2011) confirmed a positive relationship between the level of financial resources and marketing capabilities. As a consequence for the influence on price adaptive capabilities we conclude that:

Hypothesis 2a. The higher the level of slack resources after adaptation, the higher the level of price adaptive capabilities.

In case of deploying pricing formation capabilities slack resources also act as enabler of activities because financial resources are needed for gathering relevant information regarding competitor prices and competitor tactics, which is a key resource in pricing (Dutta, Zbaracki and Bergen, 2013; Ingenbleek, 2007). Furthermore, financial resources are required for the communication of prices to customers in case customers start to negotiate prices and have to be convinced of the logic behind the pricing financial (Dutta, Zbaracki and Bergen 2003). Finally, financial resources are necessary for internal decision making to agree on prices (Dutta, Zbaracki and Bergen, 2003) at different firm levels, which is especially complex and difficult in B2B settings (Lancioni, Schau and Smith, 2005). As empirically examined by Kaleka (2011) financial resources can be used for the acquisition of relevant, competitor related information. We conclude that:

Hypothesis 2b: The higher the level of slack resources after adaptation, the higher the level of price formation capabilities.

In addition to the relationship between resources and capabilities we also want to look at the mutual influence between the pricing capabilities. Dutta, Zbaracki and Bergen (2003) suggest that all price changing decisions should be the result of pricing formation capabilities. In a similar vein Chakravarthy (1982) emphasizes that investments in marketing capabilities are necessary investments in adaptive capabilities. Due to the fact that competitive based information gathering and processing as well as internal resource allocation represent prerequisites for adaptive capability (McKee, Varadarajan and Pride, 1989; Walker and Rueckert, 1987) we assume that price formation capabilities are a prerequisite for price adaptive capabilities (i.e. an adaptive capability regarding prices) and propose the following:

Hypothesis 3. The higher the level of price formation capabilities, the higher the level of price adaptive capabilities.

To give evidence about a price reaction after market entry we are going to consider each factor of the amc-framework hereafter.

Regarding the awareness, we assume that competitive dynamics in international contexts are highly visible (Chen, Smith and Grimm, 1992; Smith and Grimm, 1991), meaning that home country firms are monitoring of their international competitors continuously activities even if there are no hints for competitive movements (Yu and Cannella, 2007).

Regarding the capability we tie in with Teece, Pisano and Shuen (1997) who claim that capabilities are processes and routines by which a firm transfers its resources into valuable output and that they evolve from the routines of responding to similar problems over a longer period (Grant, 1996; Nelson and Winter, 1982). Due to the fact that pricing capabilities are essential for firm survival (Dutta et al., 2002) we argue that every company has a certain basic level available and that there only exist level differences between firms. Thus, the capability to react is a present resource in every company and the price reaction depends on the motivation to react.

The motivation to react will increase with an enhancement in the perceived threat of competitive actions (Chen and Miller, 1994; Debruyne, Frambach and Moenaert, 2010). Abundance with resources and capabilities decreases the motivation to react (Debruyne, Frambach and Moenaert, 2010) because firms pertaining adequate resources feel less threatened by competitive pressure (Chen, Smith and Grimm, 1992; Chen and Miller, 1994; Smith, Ferrier and Ndofor, 2001). The higher the amount of slack resources, the less the perceived threat (Kraatz and Zajac, 2001) because of the resources' function as environmental buffer (Thompson, 1967). According to the theory of strategic issue diagnosis (Daft and Weick, 1984; Dutton and Duncan, 1987) firms interpret their environments by categorizing strategic issues as either opportunities or threats (Miller and Lin, 2015). Denison et al. (1996) empirically proved that firms incorporating 
a high amount of capabilities perceive activities in their competitive environment rather as a threat than as an opportunity, in contrast to firms with fewer capabilities which perceive competitive movements as more harmful. Consequently, firms with a large amount of resources and capabilities will feel superior against competitors and perceive competitive actions as less threatening (Debruyne, Frambach and Moenaert, 2010).

According to the resource advantage theory (Hunt and Morgan, 1997) firms that already possess a high level of resources expect their competitor to be less successful in the market (Debruyne, Frambach and Moenaert, 2010) because the higher the current capability level, the easier it is to add on it and sustain competitive advantage (Dierickx and Cool, 1989; Srivastava, Shervani and Fahey, 1998).

Taken these aspects together, we suppose that the more price adaptive capabilities a firm has the more superior it feels against competitors and the less it perceives competitive actions as a threat. Consequently, the motivation to react with price decreases along with an increase in the level of price adaptive capabilities.

Therefore, we assume that:

Hypothesis 4. The higher the level of price adaptive capabilities, the less pronounced the price reaction- $t_{1}$.

Figure 2 summarizes the underlying hypotheses of this paper:

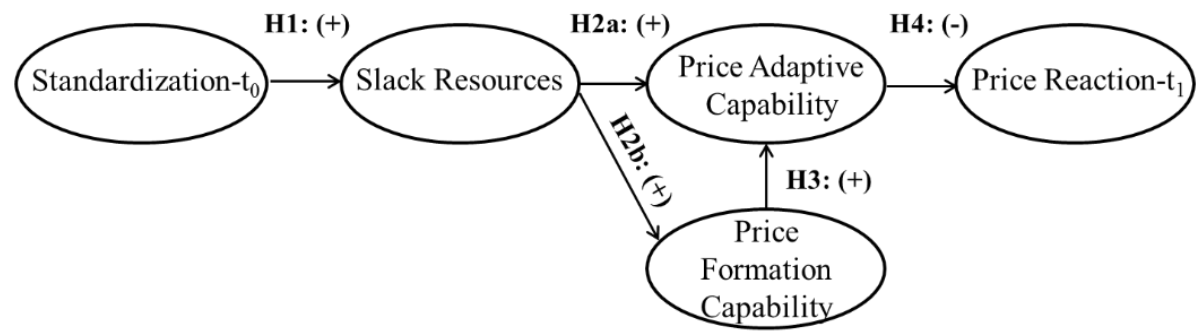

Figure 2. Underlying Hypotheses for the relationship of standardization and price reaction

\section{Methods}

\subsection{Data Collection and Sample Structure}

For the collection of primary data from a multiple-industry survey of export ventures, we developed a survey instrument, containing original measures from prior literature. With a pretest, we ensured that the questionnaire could be comprehended by marketing and sales practitioners and elicited adequate responses. Marketing and sales managers from international corporations agreed to fill out the survey and indicate any problematic or unclear formulations, which resulted in some minor alternations. Overall the pretest indicated that the survey instrument was well understood and could easily be filled out by participants.

We sent the final version of the online survey instrument to corporate key informants, as recommended by Kumar, Stern and Anderson (1993). For the quantitative investigation, we concentrated on firms located in Germany exporting industrial goods to Emerging Markets. We asked them to focus on their most important export market. In particular, these organizations provided chemical products, machinery and equipment, electro-technics, basic metals, fabricated metal products and transportation equipment. Thus the sample consists of diversified industries. The contacting of key informants was mainly realized via the Xing business database (a German equivalent to LinkedIn) as a sampling frame (Herbst and Merz, 2011). After ensuring that the firms are engaged in export activities in Emerging Markets, 257 top executives from different firms were invited via e-mail to participate in our online study, 144 of whom submitted the questionnaire. We excluded respondents who did not complete the entire survey or did not address the issue of an Emerging Market (e.g. for Great Britain) leaving a sample of 136 respondents.

The majority of the surveyed firms undertake export activities in Middle and East Europe (48 \%). Furthermore, 38 percent of the firms export to Asian markets followed by South American (11\%) and African markets (4\%). Most key informants served as export directors (44\%) or sales managers (38.8\%); thus, we succeeded in obtaining information from export managers about export-related issues.

\subsection{Description of Measures}

If available, we used existing scales or adapted versions of them to our study context. We assumed standardization, price formation capabilities and price adaptive capabilities to be formative in nature and slack resources after adaptation as well as price reaction to be reflective in nature. We measured all the indicators (see the Appendix) on a six-point Likert-scale. 
Standardization- $t_{0}$ : To measure the degree of price and product standardization at market entry, we adopted four indicators from Lages and Montgomery (2005), Navarro, Acedo, Robson, Ruzo and Losada (2010) and Shoham (1999). Since we included price and product related aspects as indicators we measured this construct in a formative nature as already empirically employed by Navarro et al. (2010) and Navarro, Acedo, Losada and Ruzo (2011). We used a six-point Likert-scale ranging from $1=$ "not standardized" to $6=$ "highly standardized".

Slack resources after adaptation: We examine slack resources after adaptation as the quantity of financial resources, which was not used/needed for the implementation of pricing adaptation at market entry. On the basis of the reflective measurement of slack resources by Kaleka (2011); Miller and Friesen (1982) and Oktemgil and Greenley (1997) we modified four indicators so that they reflect the degree of slack resources that were available after market entry. The Likert-scale is anchored by $1=$ "very rarely" and $6=$ "very substantial".

Price adaptive capability: On the basis of the adaptive capability construct described by Chakravarthy (1982), Miles and Cameron (1982) and Oktemgil and Greenley (1997) price adaptive capability refers to the extent to which export ventures can use pricing skills to respond quickly to competitors' actions and customer changes. We measured it by two items adapted from Murray, Gao and Kotabe (2011). Managers were asked to evaluate their pricing capabilities in comparison to their competitors on a scale running from $1=$ "much worse" to $6=$ "much better" (Vorhies and Morgan, 2005).

Price formation capability: We measured price formation capabilities by the use of four items. We define pricing capabilities as the capabilities which do an effective job of pricing own products, monitor competitors' prices and the knowledge of competitors' tactics (Vorhies and Morgan, 2005). Furthermore, we adapted one item from Murray, Gao and Kotabe (2011) and Liozu and Hinterhuber (2014) to also capture the extent to which the export venture can communicate price changes to customers. In line with price formation capabilities was measured in comparison to their competitors on a Likert-scale running from $1=$ "much worse" to $6=$ "much better".

Price reaction- $t_{1}$ : We adapted the measurement of price reaction after market entry from Debruyne et al. (2002) and Kuester, Homburg and Robertson (1999) and who describe it as the degree to which the pricing differs from the pricing at market entry. We used two indicators, list price and discount policies which are both highly relevant within industrial industries (Dutta, Zbaracki and Bergen, 2003). To capture the price reaction within this reflective construct, the Likert-scale was anchored by $1=$ "not changed at all" to $6=$ "changed substantially".

By applying these measures, we paid particular attention to the threat of common method biases. We had to gather the independent and dependent data from the same source since no objective source of data for each export venture was available. We followed the advice of Podsakoff, MacKenzie, Lee and Podsakoff (2003) to reduce the threat of such potential sources of common method bias. First, during the ex ante research design stage, we ensured that the items and questionnaire as a whole were as concise as possible. Second, we separated the measurement of predictor and criterion variables in the questionnaire and used different scale types, response formats, and scale endpoints. Third, respondents' answers were anonymous. Fourth, with our pretests, we reduced any comprehension problems prior to the survey.

Due to the fact that formative as well as reflective constructs were included, ex post statistical analyses as suggested by Podsakoff et al. (2003) could not be employed. Therefore, we cannot assume the absence of some kind of common method bias.

\section{Measure Assessment}

We used the statistics tool PLS (partial least squares) because this tool is suitable for analyzing and evaluating models containing both formative and reflective latent variables (Diamantopoulos, 1999; Diamantopoulos and Winklhofer, 2001) and can be used on small samples, which is the case here (136 firms). Furthermore, PLS is to be preferred if the investigated constructs are newly conceptualized and the measurement is not yet proven (Chin and Newsted, 1999). Especially in the context of international marketing (Henseler, Ringle and Sinkovics, 2009) PLS is of high interest to researchers. There is no general index to evaluate the complete model, however there exist several indices that estimate quality and data fit (Chin, 1998; Fornell and Larcker, 1981). PLS models are analyzed and interpreted in two stages, i.e. the measurement (outer) model has to be evaluated prior to the analysis of the structural (inner) model.

Evaluation of the measurement model. The analysis of individual reliability of reflective indicators involves examining the loadings or simple correlations of the indicators with the construct which the items are supposed to measure: It should be greater than .7 to meet indicator reliability (Henseler, Ringle and Sinkovics, 2009). Table 1 reports the results showing that the requested value for all reflective constructs are achieved. Furthermore, all items have significant factor loadings at the levels of $\mathrm{p}<.01$, with bootstrap critical ratios greater than 2.59 (Chin, 1998). Every construct meets the minimum AVE value of .5 and the composite reliability of all constructs exceeds the requested value of .6 (Bagozzi and Yi, 1988). For the evaluation of the discriminant validity each construct's AVE should be higher than its squared 
correlation with any other construct (Fornell and Larcker, 1981). Slack resources and price reaction complied with this condition. Thus convergent validity and discriminant validity of the reflective constructs are supported. Table 1 reports the results.

Table 1. Reflective constructs: reliability and validity of items and constructs.

\begin{tabular}{lccccc}
\hline Constructs & $\begin{array}{c}\text { Loadings } \\
(\geq .7)\end{array}$ & $\begin{array}{c}\text { Critical } \\
\text { Ratio } \\
(\geq 2.58)\end{array}$ & $\begin{array}{c}\text { AVE } \\
(\geq .5)\end{array}$ & $\begin{array}{c}\text { Composite } \\
\text { Reliability } \\
(\geq .6)\end{array}$ & $\begin{array}{c}\text { Squared } \\
\text { Correlation } \\
\text { (< AVE) }\end{array}$ \\
\hline Slack resources & .808 & 16.289 & & & \\
Slack_1 & .877 & 27.480 & .731 & .916 & \\
Slack_2 & .856 & 29.505 & & & .003 \\
Slack_3 & .877 & 22.218 & & & \\
Slack_4 & & & & & \\
Price reaction-t $t_{1}$ & .885 & 6.560 & .766 & & \\
PriceReaction_1 & .865 & 5.549 & & & \\
PriceReaction_2 & & &
\end{tabular}

AVE=Average Variance Extracted

For the evaluation of the individual reliability of indicators in formative constructs the weights, which indicate the relative importance of each indicator in the formation of the latent variable, are of interest. Although Bollen and Lennox (1991) do not recommend eliminating any indicators of formative variables due to potential information loss, we followed Seltin and Keeves (1994) and excluded two indicators with weights <.1. As a result of the bootstrapping procedure the significance of the weights can also be evaluated by means of the t-values. Although three indicators appear to be not significant, they were not eliminated due to concerns regarding the content of construct (Diamantopoulos and Winklhofer, 2001). Henseler, Ringle and Sinkovics (2009) warn researchers to discard formative indicators just on the basis of statistical outcomes and recommend keeping both significant and insignificant formative indicators in the measurement model as long as this is conceptually justified. According to Diamantopoulos and Winklhofer (2001), MacKenzie, Podsakoff and Jarvis (2005) and Diamantopoulos and Siguaw (2006), a fundamental problem with formative constructs constitutes the possible existence of multicollinearity because of the potential for unstable indicator weights. It can be assessed by calculating the variance inflation factors (VIF). In line with the indicator weights Table 2 shows that all the formative indicators included in the study have a VIF of less than 5 (Hair, Ringle and Sarstedt, 2011).

Table 2. Formative constructs: weights and collinearity test.

\begin{tabular}{|c|c|c|c|}
\hline Constructs & $\begin{array}{l}\text { Weights } \\
(>|1|)\end{array}$ & t-Value & $\begin{array}{c}\text { Collinearity (VIF) } \\
(\leq 5)\end{array}$ \\
\hline \multicolumn{4}{|c|}{ Standardization- $\mathrm{t}_{0}$} \\
\hline Standard_1 & .118 & .301 & 1.519 \\
\hline Standard_2 & .220 & .543 & 1.513 \\
\hline Standard_3 & & Eliminated & \\
\hline Standard_4 & .894 & $2.776 * *$ & 1.643 \\
\hline \multicolumn{4}{|c|}{ Price adaptive capability } \\
\hline Adaptive_1 & .429 & $3.183^{* *}$ & 1.734 \\
\hline Adaptive_4 & .666 & $5.480 * *$ & 1.734 \\
\hline \multicolumn{4}{|c|}{ Price formation capability } \\
\hline Formation_2 & .107 & .993 & 1.698 \\
\hline Formation_3 & .294 & $3.181 * *$ & 1.512 \\
\hline Formation_5 & & Eliminated & \\
\hline Formation_6 & .826 & $10.909 * *$ & 1.588 \\
\hline
\end{tabular}

$\mathrm{VIF}=$ Variance Inflation Factor

The evaluation of the reliability of constructs is only possible with reflective indicators since formative indicators will not be correlated (Chin 1998). Similarly, formative measures' convergent and discriminant validities cannot be assessed by empirical means (e.g. Hair, Ringle and Sarstedt, 2011).

Evaluation of the structural model. Subsequent to the evaluation of validity and reliability of the measurement model we verified the relations between the latent variables by examining whether the structural model supports the proposed research model. We tested the model considering the intensity of the path coefficients (or standardized regression weights) and the coefficient of determination ( $\mathrm{R}^{2}$ value) of the endogenous variables. According to Falk and Miller (1992) the variance explained should be greater than or equal to .1 to be adequate. The results obtained (Table 3) show 
that price adaptive capability is the only variable that meets this minimum threshold. However, the evaluation of the structural model should not be limited to $\mathrm{R}^{2}$ because it is related to the study context and varies with the complexity of the structural model (Hair, Hult, Ringle and Sarstedt, 2014). Our structural model is characterized by high complexity because mostly only one exogenous variable influences one endogenous variable. Furthermore, Navarro et al. (2010) came to similar values of $\mathrm{R}^{2}$ in the context of international marketing issues. In addition to $\mathrm{R}^{2}$ Hair et al. (2014) and Hair, Sarstedt, Ringle and Mena (2012) recommend measuring the effect size $\mathrm{f}^{2}$ and the predictive relevance $\mathrm{Q}^{2}$.

The effect size represents the change in $\mathrm{R}^{2}$ when an exogenous construct is omitted from the model. Thus, it can be used to evaluate if the omitted construct has a substantive impact on the endogenous construct. Chin (1998) establishes that these coefficients should equal at least .2, but ideally exceed .3, to be acceptable. Table 3 shows that the relation between price formation and price adaptive capability meets this condition. In contrast the influence of slack resources after adaptation on price adaptive capability seems to be negligible. The predictive relevance $\mathrm{Q}^{2}$ which can only be estimated for reflective constructs should exceed values > 0 (Chin, 1998). As Table 3 indicates both reflective variables slack resources and price reaction meet this condition.

Table 3. Variance explained, effect size and predictive relevance of dependent variables.

\begin{tabular}{lccc}
\hline Construct & $\mathbf{R}^{2}$ & $\mathbf{f}^{2}$ & $\mathbf{Q}^{2}$ \\
\hline Slack resources & & Price adaptive capability & \\
Price adaptive capability & .058 & .002 & .041 \\
Price formation capability & .514 & - & - \\
${\text { Price reaction- } t_{1}}$ & .080 & .973 & - \\
\hline
\end{tabular}

In order to test the proposed research hypotheses we calculated the accuracy and stability of the estimates obtained in a next step. By making use of the bootstrap technique the path coefficient values and the t-values of the model parameters are provided. Table 4 shows the results of this analysis.

Table 4. Path coefficient values for direct relations proposed in model.

\begin{tabular}{|c|c|c|c|c|}
\hline & Proposed relations & & $\begin{array}{c}\text { Path } \\
\text { coefficients } \\
(\geq|.1|)\end{array}$ & t-Value \\
\hline H1: & $\begin{array}{l}\text { Standardization- } \mathrm{t}_{0} \\
\rightarrow \text { Slack resources }\end{array}$ & + & .241 & $2.365^{*}$ \\
\hline H2a: & $\begin{array}{l}\text { Slack resources } \\
\rightarrow \text { Price adaptive capability }\end{array}$ & + & -.001 & .136 \\
\hline $\mathrm{H} 2 \mathrm{~b}:$ & $\begin{array}{l}\text { Slack resources } \\
\rightarrow \text { Price formation capability }\end{array}$ & + & .282 & $2.977 * *$ \\
\hline H3: & $\begin{array}{l}\text { Price formation capability } \\
\rightarrow \text { Price adaptive capability }\end{array}$ & + & .719 & $13.289 * *$ \\
\hline H4: & $\begin{array}{l}\text { Price adaptive capability } \\
\rightarrow \text { Price reaction- } t_{1}\end{array}$ & - & -.226 & $2.574 *$ \\
\hline
\end{tabular}

The results obtained provide support for Hypotheses $\mathrm{H} 1, \mathrm{H} 2 \mathrm{~b}, \mathrm{H} 3$ and $\mathrm{H} 4$ since all the relations have the expected sign and are significant. Therefore, it could be confirmed that the standardization of price and product related aspects results in an increase of slack resources after adaptation decision (H1) which have a positive influence on the price formation capability $(\mathrm{H} 2 \mathrm{~b})$. Furthermore, the higher the price formation capability the higher the price adaptive capability will be (H3). Finally, the decreasing effect of price adaptive capability on the strength of the price reaction could also be confirmed (H4). However, the results did not verify that firms with a high amount of slack resources after adaptation can increase their price adaptive capability due to the fact that the path coefficient does not exceed .1 and is not significant. Thus, only an indirect relation between slack resources after adaptation and price adaptive capability via price formation capability is confirmed. The value of this indirect effect is calculated by multiplying the standardized regression coefficients between each pair of constructs: $(.282 * .789=.203)$. 
Figure 3 demonstrates the results of the evaluation of the structural model.

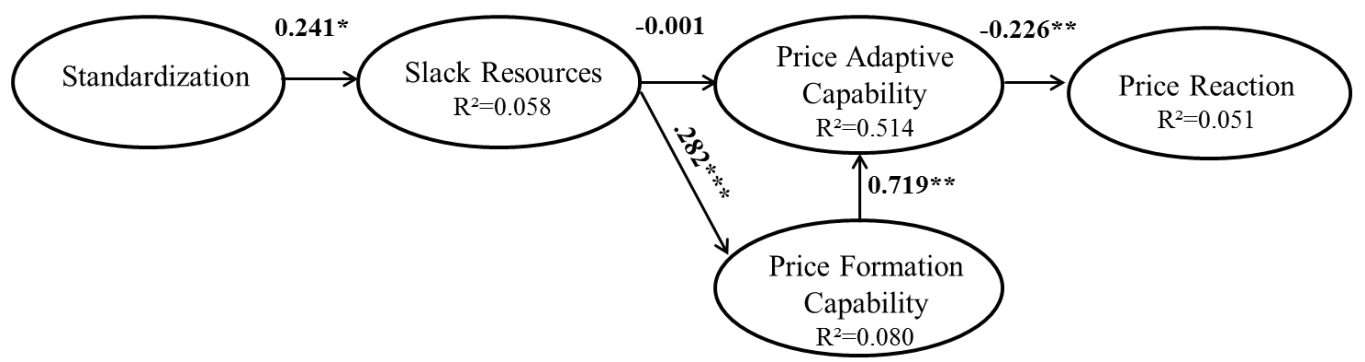

$* \mathrm{p}<0.05 ; * \mathrm{p}<0.001$

Figure 3. Evaluation of the structural model

We included three control variables, firm size, industry, and market entry time. None of the control variables did have a significant effect on the path coefficients of the structural model.

\section{Discussion, Implications and Future Research}

\subsection{Discussion}

This work provides important contributions to the international marketing literature drawn from the comprehensive analysis of relationships between price and product standardization at market entry and price reaction after market entry. Based on the concept of path dependencies it contributes to the evolutionary character of standardization by linking it to subsequent marketing decisions. Furthermore, it was clarified that standardization contributes to resource allocation aspects (Szymanski, Bharadwaj and Varadarajan, 1993; Navarro et al., 2010) due to its positive influence on slack resources after adaptation. Those slack resources directly enhance the price formation capability but do not influence the price adaptive capability. That may be the case because they are primary necessary for the comprehensive information gathering and information processing which constitute one characteristic of the price formation capability (Vorhies and Morgan, 2005).

Additionally, this study confirmed that price formation capability is a precondition for the price adaptive capability. Therefore, the sole availability of slack resources is not sufficient to change list prices and discount policies according to changes of the competitive environment or changes of customer preferences. Instead the capability to generate continuously relevant information about competitors' prices and competitors' tactics, the capability to do an effective job of pricing own products (Vorhies and Morgan, 2005) and the capability to be able to communicate price changes to customers (Murray, Gao and Kotabe, 2011) are necessary to enhance the adaptation of prices. Thus, the price adaptive capability is the result of a conscious resource allocation (McKee, Varadarajan and Pride, 1989; Walker and Rueckert, 1987).

Moreover it was confirmed that price adaptive capabilities decrease the strength of a price reaction. As postulated on the basis of the amc-framework, the higher the firm's capabilities, the lower its motivation to react to competitors' moves (e.g. Debruyne, Frambach and Moenaert, 2010).

Thus, this study also delivers important insights into competitive marketing behavior in international marketing decisions.

To sum up, firms that mostly standardize prices and products at market entry will increase their slack resources after adaptation. As a result price formation capabilities and price adaptive capabilities are enhanced which lead to a lower motivation to change the price after market entry. In reverse, firms that mostly adapt prices and products at market entry will have a lower amount of slack resources available leading to lower price formation capabilities and price adaptive capabilities which result in a higher perceived threat of the competitor's move leading to a price reaction. Figure 4 summarizes these results in dependence on the market entry decision. 


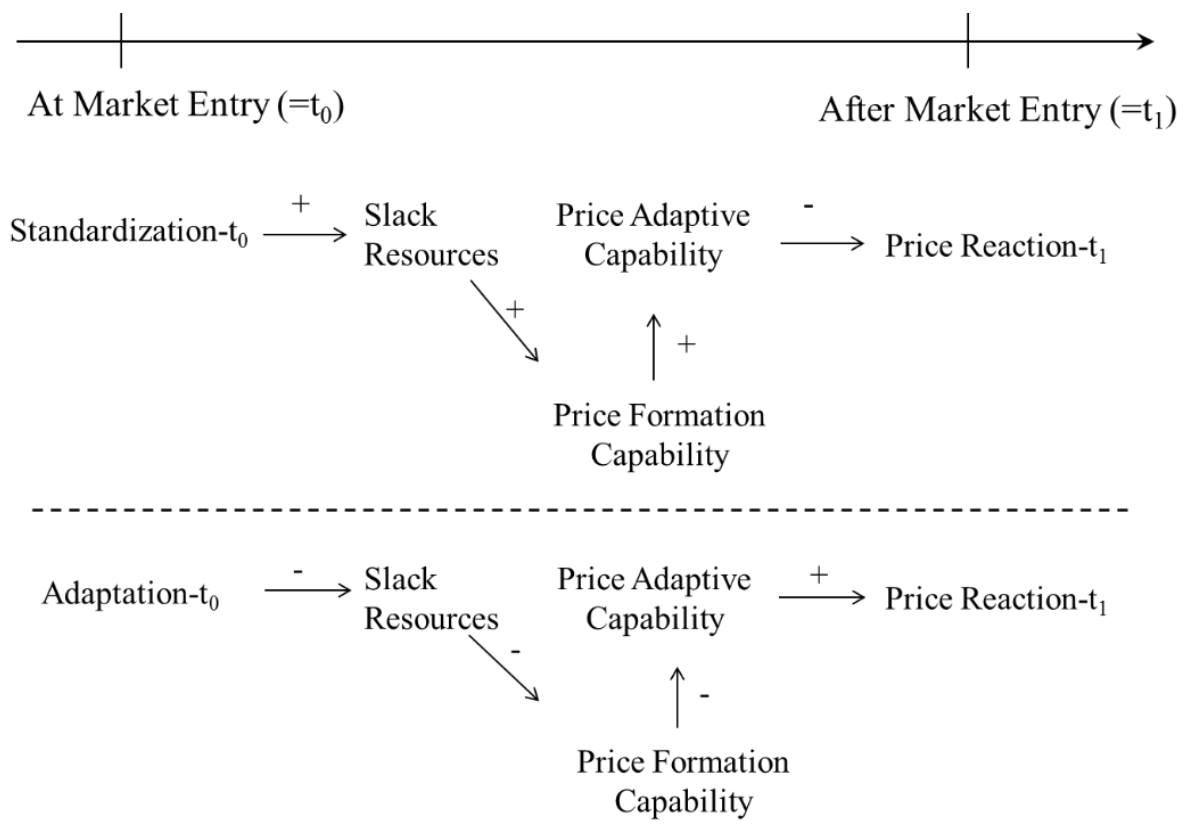

Figure 4. Final recommendations in dependence on the market entry decision

This study could empirically prove that the marketing-mix standardization at market entry influences marketing-mix decisions after market entry related to competitive defending behavior. According to the assumptions of path dependencies interdependencies between market entry decisions that are related to resource allocation issues and the use and impact of resources and capabilities in competitive reaction behavior could be confirmed. Thus, this paper provides a link between the two streams of international marketing and competitive dynamics.

\subsection{Implications}

The authors could make clear that international marketing-mix decisions are dependent and cannot be treated separately at a single point of time. Managers must be aware of this fact and need to consider the interdependencies in their decision-making processes. Furthermore, the relationship of standardization aspects and resources can be helpful for more comprehensive and precise competitive intelligence like e.g. the investments in competition analysis and monitoring. Additionally, managers have to be careful because of the negative effect of high price related capabilities on price reaction which could diminish the outcomes of defensive behavior (Gatignon, Robertson and Fein, 1997). Firms that feel less threatened by their competitors tend to underestimate external influences (Debruyne, Frambach and Moenaert, 2010) which could lead to competitive inertia on the expense of competitive adaptive behavior (Miller and Chen, 1994).

\subsection{Limitations and Future Research}

In our study we concentrated on the standardization of product and price related aspects. Future research could also include the standardization of distribution and communication to develop a broader look on the international marketing-mix. Furthermore, a more comprehensive analysis on the role of standardization issues as independent variable is necessary. Especially in the context of path dependencies, more outcomes in the context of international marketing-mix decisions have to be identified.

Moreover, we did not analyze the effects according to the business types of industrial goods. Due to their special idiosyncrasies each business type varies in its standardization potential (Backhaus and Muehlfeld, 2005; Helm and Gritsch, 2014) and therefore might generate different results. Future studies should be related to this point.

Another limitation of this study can be seen in the assumption that slack resources are supposed to have a positive effect on capabilities. In contrast, Nohria and Gulati (1996) suppose an inverted u-shaped influence on internal aspects in the context of innovation related behavior.

Furthermore, future research should shed more light on the outcomes of price related capabilities which still lack academic research (Liozu, 2016). 
Finally, the effect of price reactions on a firm's performance is still missing. In the field of international marketing researchers could consider whether a price reaction enhances or diminishes the export performance.

\section{References}

Albaum, G., \& Tse, D. K. T. (2001). Adaptation of international marketing strategy components, competitive advantage, and firm performance: a study of Hong Kong exporters. Journal of International Marketing, 9(4), 59-81. https://doi.org/10.1509/jimk.9.4.59.19943

Amit, R., \& Schoemaker, P. J. H. (1993). Strategic assets and organizational rent. Strategic Management Journal, 14(1), 33-46. https://doi.org/10.1002/smj.4250140105

Anderson, E., \& Gatignon, H. (1986). Modes of foreign entry: a transaction cost analysis and propositions. Journal of International Business Studies, 17(3), 1-26. https://doi.org/10.1057/palgrave.jibs.8490432

Backhaus, K., \& Muehlfeld, K. (2005). Strategy dynamics in industrial marketing: a business types perspective. Management Decision, 43(1), 38-55. https://doi.org/10.1108/00251740510572470

Bagozzi, R. P., \& Yi, Y. (1988). On the evaluation of structural equation models. Journal of the Academy of Marketing Science, 16(Spring), 74-94. https://doi.org/10.1007/BF02723327

Barney, J. B. (1986). Strategic factor markets: expectations, luck, and business strategy. Management Science, 32(10), 1231-41. https://doi.org/10.1287/mnsc.32.10.1231

Beckman, C. M., \& Burton, D. M. (2008). Founding the future: path dependence in the evolution of top management teams from founding to IPO. Organization Science, 19(1), 3-24. https://doi.org/10.1287/orsc.1070.0311

Birnik, A., \& Bowman, C. (2007). Marketing mix standardization in multinational corporations: a review of the evidence. International Journal of Management Reviews, 9(4), 303-24. https://doi.org/10.1111/j.1468-2370.2007.00213.x

Bourgeois, J. L. (1981). On the measurement of organizational slack. Academy of Management Review, 6(1), 29-39. https://doi.org/10.5465/amr.1981.4287985

Bowman, D., \& Gatignon, H. (1995). Determinants of competitor response time to a new product introduction. Journal of Marketing Research, 32(1), 42-53. https://doi.org/10.2307/3152109

Brouthers, K. D. (2013). A retrospective on institutional, cultural and transaction cost influences on entry mode choice and performance. Journal of International Business Studies, 44(1), 14-22. https://doi.org/10.1057/jibs.2012.23

Cavusgil, T. S., \& Zou, S. (1994). Marketing strategy-performance relationship: an investigation of the empirical link in export market ventures. The Journal of Marketing, 1-21. https://doi.org/10.2307/1252247

Cavusgil, T. S., Zou, S., \& Naidu, G. M. (1993). Product and promotion adaptation in export ventures: an empirical investigation.. Journal of International Business Studies, 24(3), $479-506$. https://doi.org/10.1057/palgrave.jibs.8490242

Chakravarthy, B. S. (1982). Adaptation: A promising metaphor for strategic management. Academy of Management Review, 7(1), 35-44. https://doi.org/10.5465/amr.1982.4285438

Chang, S. J. (1995). International expansion strategy of Japanese firms: capability building through sequential entry. Academy of Management Journal, 38(2), 383-407. https://doi.org/10.5465/256685

Chen, M. J. (1996). Competitor analysis and interfirm rivalry: toward a theoretical integration. Academy of Management Review, 21(1), 100-34. https://doi.org/10.5465/amr.1996.9602161567

Chen, M. J., \& Miller, D. (1994). Competitive attack, retaliation and performance: an expectancy - valence framework. Strategic Management Journal, 15(2), 85-102. https://doi.org/10.1002/smj.4250150202

Chen, M. J., Smith, K. G., \& Grimm, C. M. (1992). Action characteristics as predictors of competitive responses. Management science, 38(3), 439-455. https://doi.org/10.1287/mnsc.38.3.439

Chen, M. J., Su, K. H., \& Tsai, W. (2007). Competitive tension: The awareness-motivation-capability perspective. Academy of Management Journal, 50(1), 101-118. https://doi.org/10.5465/amj.2007.24162081

Chin, W. W. (1998). The partial least squares approach to structural equation modeling. Modern methods for business research, Marcoulides GA (ed). Psychology Press: Mahwah: 295-358.

Chin, W. W., \& Newsted, P. R. (1999). Structural equation modeling analysis with small samples using partial least squares. Statistical strategies for small sample research, 1(1), 307-341.

Christenson, C. J. (1973). The 'Contingency Theory' of organization. Working Paper, Harvard Business School. 
Daft, R. L., \& Weick, K. E. (1984). Toward a model of organizations as interpretation systems. Academy of Management Review, 9(2), 284-95. https://doi.org/10.5465/amr.1984.4277657

Daniel, F., Lohrke, F. T., Fornaciari, C. J., \& Turner Jr., A. R. (2004). Slack resources and firm performance: a meta-analysis. Journal of Business Research, 57(6), 565-74. https://doi.org/10.1016/S0148-2963(02)00439-3

Day, G. S. (1994). The capabilities of market-driven organizations. Journal of Marketing, 37-52. https://doi.org/10.2307/1251915

Debruyne, M., Frambach, R. T., \& Moenaert, R. (2010). Using the weapons you have: the role of resources and competitor orientation as enablers and inhibitors of competitive reaction to new products. Journal of Product Innovation Management, 27(2), 161-78. https://doi.org/10.1111/j.1540-5885.2010.00708.x

Debruyne, M., Moenaertb, R., Griffinc, A., Hartd, S., Hultinke, E. J., \& Robben, H. (2002). The impact of new product launch strategies on competitive reaction in industrial markets. Journal of Product Innovation Management: An International Publication of The Product Development \& Management Association, 19(2), 159-170. https://doi.org/10.1016/S0737-6782(01)00135-7

Denison, D. R., Dutton, J. E., Kahn, J. A., \& Hart, S. A. (1996). Organizational context and the interpretation of strategic issues: a note on CEO's interpretation of foreign investment. Journal of Management Studies, 33(4), 45374. https://doi.org/10.1111/j.1467-6486.1996.tb00164.x

Diamantopoulos, A. (1999). Viewpoint-export performance measurement: reflective versus formative indicators. International Marketing Review, 16(6), 444-57. https://doi.org/10.1108/02651339910300422

Diamantopoulos, A., \& Siguaw, J. A. (2006). Formative versus reflective indicators in organizational measure development: A comparison and empirical illustration. British Journal of Management, 17(4), 263-282. https://doi.org/10.1111/j.1467-8551.2006.00500.x

Diamantopoulos, A., \& Winklhofer, H. M. (2001). Index construction with formative indicators: An alternative to scale development. Journal of marketing research, 38(2), 269-277. https://doi.org/10.1509/jmkr.38.2.269.18845

Dierickx, I., \& Cool, K. (1989). Asset stock accumulation and sustainability of competitive advantage. Management Science, 35(12), 1504-511. https://doi.org/10.1287/mnsc.35.12.1504

Donada, C., \& Dostaler, I. (2005). Relational antecedents of organizational slack: an empirical study into supplier-customer relationships. Management, 8(2), 25-46. https://doi.org/10.3917/mana.082.0025

Douglas, S. P., \& Craig, C. S. (2011). Convergence and divergence: Developing a semiglobal marketing strategy. Journal of International Marketing, 19(1), 82-101. https://doi.org/10.1509/jimk.19.1.82

Douglas, S. P., \& Craig, S. C. (1989). Scale, scope and synergy: The evolution of global marketing strategy. Columbia Journal of World Business, (Fall) 47-59.

Douglas, S. P., \& Wind, Y. (1987). The myth of globalization. Columbia Journal of World Business, 22(4), 19-29.

Dow, D. (2006). Adaptation and performance in foreign markets: evidence of systematic under-adaptation. Journal of International Business Studies, 37(2), 212-26. https://doi.org/10.1057/palgrave.jibs.8400189

Dutta, S., Bergen, M., Ritson, M., \& Zbaracki, M. J. (2002). Pricing as a strategic capability. Sloan Management Review, 43(3), 61-66.

Dutta, S., Zbaracki, M. J., \& Bergen, M. (2003). Pricing process as a capability: a resource-based perspective. Strategic Management Journal, 24(7), 615-30. https://doi.org/10.1002/smj.323

Dutton, J. E., \& Duncan, R. B. (1987). The creation of momentum for change through the process of strategic issue diagnosis. Strategic Management Journal, 8(3), 279-95. https://doi.org/10.1002/smj.4250080306

Eisenhardt, K. M., \& Martin, J. A. (2000). Dynamic capabilities: what are they?, Strategic Management Journal, 21(10-11), 1105-21. https://doi.org/10.1002/1097-0266(200010/11)21:10/11<1105::AID-SMJ133>3.0.CO;2-E

Falk, R. F., \& Miller, N. B. (1992). A primer for soft modeling. University of Akron Press: Akron, OH.

Ferrier, W. J. (2001). Navigating the competitive landscape: the drivers and consequences of competitive aggressiveness. Academy of Management Journal, 44(4), 858-77.

Filipe, L. L., \& Montgomery, D. B. (2005). The relationship between export assistance and performance improvement in Portuguese export ventures: An empirical test of the mediating role of pricing strategy adaptation. European Journal of marketing, 39(7/8), 755-784. https://doi.org/10.1108/03090560510601752

Fornell, C., \& Larcker, D. F. (1981). Evaluating structural equation models with unobservable variables and 
measurement error. Journal of Marketing Research, 18(1), 39-50. https://doi.org/10.2307/3151312

Gatignon, H., \& Xuereb, J. M. (1997). Strategic orientation of the firm and new product performance. Journal of marketing research, 77-90. https://doi.org/10.2307/3152066

Gatignon, H., Robertson, T. S., \& Fein, A. S. (1997). Incumbent defense strategies against new product entry. International Journal of Research in Marketing, 14(2), 163-76. https://doi.org/10.1016/S0167-8116(96)00035-3

Grant, R. M. (1996). Prospering in dynamically-competitive environments: organizational capability as knowledge integration. Organization Science, 7(4), 375-87. https://doi.org/10.1287/orsc.7.4.375

Hair, J. F., Ringle, C. M., \& Sarstedt, M. (2011). PLS-SEM: Indeed a silver bullet. Journal of Marketing theory and Practice, 19(2), 139-152. https://doi.org/10.2753/MTP1069-6679190202

Hair, J. F., Sarstedt, M., Ringle, C. M., \& Mena, J. A. (2012). An assessment of the use of partial least squares structural equation modeling in marketing research. Journal of the academy of marketing science, 40(3), 414-433. https://doi.org/10.1007/s11747-011-0261-6

Hair, J. F. G., Hult, T. M., Ringle, C. M., \& Sarstedt, M. (2014). A primer on partial least squares structural equation modelling (PLS-SEM). Sage: Thousand Oaks, CA.

Hannan, M. T., \& Freeman, J. (1984). Structural inertia and organizational change. American Sociological Review, 14964. https://doi.org/10.2307/2095567

Heil, O. P., \& Helsen, K. (2001). Toward an understanding of price wars: their nature and how they erupt. International Journal of Research in Marketing, 18(1), 83-98. https://doi.org/10.1016/S0167-8116(01)00033-7

Helm, R., \& Gritsch, S. (2014). Examining the influence of uncertainty on marketing mix strategy elements in emerging business-to-business export markets. International Business Review, 23(2), 418-28. https://doi.org/10.1016/j.ibusrev.2013.06.007

Helm, R., Krinner, S., \& Schmalfuß, M. (2014). Conceptualization and integration of marketing intelligence: The case of an industrial manufacturer. Journal of Business-to-Business Marketing, 21(4), 237-255. https://doi.org/10.1080/1051712X.2014.979587

Henseler, J., Ringle, C. M., \& Sinkovics, R. R. (2009). The use of partial least squares path modeling in international marketing. Advances in International Marketing, 20(1), 277-319.

Herbst, U., \& Merz, M. A. (2011). The industrial brand personality scale: building strong business-to-business brands. Industrial Marketing Management, 40(7), 1072-81. https://doi.org/10.1016/j.indmarman.2011.09.003

Hunt, S. D., \& Morgan, R. M. (1997). The resource-advantage theory of competition: dynamics, path dependencies, and evolutionary dimension. Journal of Marketing, 61(1), 107-14.

Hutzschenreuter, T., \& Israel, S. (2009). A review of empirical research on dynamic competitive strategy. International Journal of Management Reviews, 11(4), 421-61. https://doi.org/10.1111/j.1468-2370.2008.00246.x

Ingenbleek, P. (2007). Value-informed pricing in its organizational context: literature review, conceptual framework, and directions for future research. Journal of Product \& Brand Management, 16(7), 441-58. https://doi.org/10.1108/10610420710834904

Jain, S. C. (1989). Standardization of international marketing strategy: some research hypotheses. Journal of Marketing, 53(1), 70-79. https://doi.org/10.2307/1251525

Kaleka, A. (2011). When exporting manufacturers compete on the basis of service: resources and marketing capabilities - driving service advantage and performance. Journal of International Marketing, 19(1), 40-58. https://doi.org/10.1509/jimk.19.1.40

Karakaya, F., \& Yannopoulos, P. (2010). Defensive strategy framework in global markets - a mental models approach. European Journal of Marketing, 44(7/8), 1077-109. https://doi.org/10.1108/03090561011047535

Katsikeas, C. S., Saeed, S., \& Theodosiou, M. (2006). Strategy fit and performance consequences of international marketing standardization. Strategic Management Journal, 27(9), 867-900. https://doi.org/10.1002/smj.549

Kirpalani, V. H., \& Macintosh, N. B. (1980). International marketing effectiveness of technology-oriented small firms. Journal of International Business Studies, 11(1), 81-90. https://doi.org/10.1057/palgrave.jibs.8490625

Kogut, B., \& Singh, H. (1988). The effect of national culture on the choice of entry mode. Journal of International Business Studies, 19(3), 411-32. https://doi.org/10.1057/palgrave.jibs.8490394

Kraatz, M. S., \& Zajac, E. J. (2001). How organizational resources affect strategic change and performance in turbulent 
environments: theory and evidence. Organization Science, 12(5), 632-57. https://doi.org/10.1287/orsc.12.5.632.10088

Kuester, S., Homburg, C., \& Robertson, T. S. (1999). Retaliatory behavior to new product entry. Journal of Marketing, 90-106. https://doi.org/10.2307/1251976

Kumar, N., Stern, L. W., \& Anderson, J. C. (1993). Conducting interorganizational research using key informants. Academy of Management Journal, 36(6), 1633-51.

Kustin, R. A. (2004). Marketing mix standardization: a cross cultural study of four countries. International Business Review, 13(5), 637-49. https://doi.org/10.1016/j.ibusrev.2004.07.001

Lages, L. F., Abrantes, J. L., \& Lages, C. R. (2008). The STRATADAPT scale - A measure of marketing strategy adaptation to international business markets. International Marketing Review, 25(5), 584-600. https://doi.org/10.1108/02651330810904107

Lancioni, R., Schau, R. J., \& Smith, M. F. (2005). Intraorganizational influences on business-to-business pricing strategies: a political economy perspective. Industrial Marketing Management, 34(2), 123-31. https://doi.org/10.1016/j.indmarman.2004.07.010

Levitt, T. (1983). The globalization of markets. Harvard Business Review, 61 (May/June), 92-102.

Liozu, S. M. (2016). The evolution and future of pricing capabilities. Journal of Revenue and Pricing Management, 15(3), 306-16. https://doi.org/10.1057/rpm.2016.20

Liozu, S. M., \& Hinterhuber, A. (2013). CEO championing of pricing, pricing capabilities and firm performance in industrial firms. Industrial Marketing Management, 42(4), 633-643. https://doi.org/10.1016/j.indmarman.2012.09.003

Liozu, S., \& Hinterhuber, A. (2014). Pricing capabilities: the design, development, and validation of a scale. Management Decision, 52(1), 144-158. https://doi.org/10.1108/MD-09-2012-0683

MacKenzie, S. B., Podsakoff, P. M., \& Jarvis, C. B. (2005). The problem of measurement model mis-specification in behavioral and organizational research and some recommended solutions. Journal of Applied Psychology, 90(4), 710-30. https://doi.org/10.1037/0021-9010.90.4.710

McKee, D. O., Varadarajan, P. R., \& Pride, W. M. (1989). Strategic adaptability and firm performance: a market-contingent perspective. Journal of Marketing, 21-35. https://doi.org/10.2307/1251340

Miles, R. H., \& Cameron, K. S. (1982). Coffin nails and corporate strategies. Prentice-Hall: Englewood Cliffs, NJ.

Miller, D. \& Chen, M. J. (1994). Sources and consequences of competitive inertia: a study of the US airline industry. Administrative Science Quarterly, 1-23. https://doi.org/10.2307/2393492

Miller, D., \& Friesen, P. H. (1983). Strategy - making and environment: the third link. Strategic management journal, 4(3), 221-235. https://doi.org/10.1002/smj.4250040304

Miller, K. D., \& Lin, S. J. (2015). Analogical reasoning for diagnosing strategic issues in dynamic and complex environments. Strategic Management Journal, 36(13), 2000-20. https://doi.org/10.1002/smj.2335

Mishina, Y., Pollock, T. G., \& Porac, J. F. (2004). Are more resources always better for growth? Resource stickiness in market and product expansion. Strategic Management Journal, 25(12), 1179-97. https://doi.org/10.1002/smj.424

Murray, J. Y., Gao, G. G., \& Kotabe, M. (2011). Market orientation and performance of export ventures: the process through marketing capabilities and competitive advantages. Journal of the Academy of Marketing Science, 39(2), 252-69. https://doi.org/10.1007/s11747-010-0195-4

Navarro, A., Acedo, F. J., Losada, F., \& Ruzo, E. (2011). Integrated model of export activity: analysis of heterogeneity in managers' orientations and perceptions on strategic marketing management in foreign markets. Journal of Marketing Theory and Practice, 19(2), 187-204. https://doi.org/10.2753/MTP1069-6679190205

Navarro, A., Acedo, F. J., Robson, M. J., Ruzo, E., \& Losada, F. (2010). Antecedents and consequences of firms' export commitment: An empirical study. Journal of International Marketing, 18(3), 41-61. https://doi.org/10.1509/jimk.18.3.41

Nelson, R. R., \& Winter, S. G. (1982). An evolutionary theory of economic change. Harvard Business School Press: Cambridge, USA.

Nohria, N., \& Gulati, T. (1996). Is slack good or bad for innovation?. Academy of Management Journal, 39(5), 1245-64. https://doi.org/10.5465/256998 
Oktemgil, M., \& Greenley, G. (1997). Consequences of high and low adaptive capability in UK companies. European Journal of Marketing, 31(7), 445-66. https://doi.org/10.1108/03090569710176619

Özsomer, A., \& Prussia, G. A. (2000). Competing perspectives in international marketing strategy: contingency and process models. Journal of International Marketing, 8(1), 27-50. https://doi.org/10.1509/jimk.8.1.27.19561

Özsomer, A., \& Simonin, B. L. (2004). Marketing program standardization: A cross-country exploration. International Journal of Research in Marketing, 21(4), 397-419. https://doi.org/10.1016/j.ijresmar.2004.06.003

Peteraf, M. A. (1993). The cornerstones of competitive advantage: a resource - based view. Strategic Management Journal, 14(3), 179-91. https://doi.org/10.1002/smj.4250140303

Pierson, P. (2000). Increasing returns, path dependence, and the study of politics. American Political Science Review, 94(2), 251-67. https://doi.org/10.2307/2586011

Podsakoff, P. M., MacKenzie, S. B., Lee, J. Y., \& Podsakoff, N. P. (2003). Common method biases in behavioral research: a critical review of the literature and recommended remedies. Journal of Applied Psychology, 88(5), 879903. https://doi.org/10.1037/0021-9010.88.5.879

Ramaswamy, V., Gatignon, H., \& Reibstein, D. J. (1994). Competitive marketing behavior in industrial markets. Journal of Marketing, 45-55. https://doi.org/10.2307/1252268

Rao, V. R. (1984). Pricing research in marketing: the state of the art. Journal of Business, 39-60. https://doi.org/10.1086/296235

Robinson, W. T. (1988). Marketing mix reactions to entry. Marketing Science, 7(4), 368-85. https://doi.org/10.1287/mksc.7.4.368

Ryans, J. K., Griffith, D. A., \& White, D. S. (2003). Standardization/adaptation of international marketing strategy. Necessary conditions for the advancement of knowledge. International Marketing Review, 20(6), 588-603. https://doi.org/10.1108/02651330310505204

Samiee, S., \& Roth, K. (1992). The influence of global marketing standardization on performance. Journal of Marketing, 1-17. https://doi.org/10.2307/1252038

Sarkar, M., \& Cavusgil, S. T. (1996). Trends in international business thought and literature: A review of international market entry mode research: integration and synthesis. The International Executive, 38(6), 825-47. https://doi.org/10.1002/tie.5060380608

Schmid, S., \& Kotulla, T. (2011). 50 years of research on international standardization and adaptation — From a systematic literature analysis to a theoretical framework. International Business Review, 20(5), 491-507. https://doi.org/10.1016/j.ibusrev.2010.09.003

Seltin, N. \& Keeves, J. P. (1994). Path analysis with latent variables. International encyclopedia of education, Husen T, Postlethwaite TN. (eds) Pergamon Press: Oxford, U.K.: 4352-4359.

Shoham, A. (1999). Bounded rationality, planning, standardization of international strategy, and export performance: a structural model examination. Journal of International Marketing, 7(2), 24-50.

Simon, D. (2005). Incumbent pricing responses to entry. Strategic Management Journal, 26(13), 1229-48. https://doi.org/10.1002/smj.502

Singh, J. V. (1986). Performance, slack, and risk taking in organizational decision making. Academy of Management Journal, 29(3), 562-85.

Skarmeas, D., Plakoyiannaki, E., Baltas, G., Kokkinaki, F., \& Hultman, M. (2016). Pricing Capabilities: Drivers and Effects on Performance. Marketing Challenges in a Turbulent Business Environment: Proceedings of the 2014 Academy of Marketing Science (AMS) World Marketing Congress (p. 323). Springer.

Slotegraaf, R., Moorman, J. M., \& Inman, J. J. (2003). The role of firm resources in returns to market deployment. Journal of Marketing Research, 18(8), 295-309. https://doi.org/10.1509/jmkr.40.3.295.19235

Smith, K. G., \& Grimm, C. M. (1991). A communication-information model of competitive response timing. Journal of Management, 17(1), 5-23. https://doi.org/10.1177/014920639101700102

Smith, K. G., Ferrier, W. J., \& Ndofor, H. (2001). Competitive dynamics research: critique and future directions. In Handbook of Strategic Management, Hitt, M, Freeman RE, Harrison, E (eds). CRC Press: London, U.K: 315-61.

Smith, K. G., Grimm, C. M., \& Gannon, M. J. (1992). Dynamics of competitive strategy. Sage Publications, Inc.

Sorenson, R. Z., \& Wiechmann, U. E. (1975). How multinationals view marketing standardization. Harvard Business 
Review, 53(3), 38-54.

Sousa, C. M. P., \& Bradley, F. (2009). Price adaptation in export markets. European Journal of Marketing, 43(3/4),: 438-58. https://doi.org/10.1108/03090560910935514

Sousa, C. M., \& Lengler, J. (2009). Psychic distance, marketing strategy and performance in export ventures of Brazilian firms. Journal of Marketing Management, 25(5-6), 591-610. https://doi.org/10.1362/026725709X461876

Srivastava, R. K., Shervani, T. A., \& Fahey, A. L. (1998). Market-based assets and shareholder value: a framework for analysis. Journal of Marketing, 2-18. https://doi.org/10.2307/1251799

Swoboda, B., \& Elsner, S. (2013). Transferring the retail format successfully into foreign countries. Journal of International Marketing, 21(1), 81-109. https://doi.org/10.1509/jim.12.0148

Sydow, J., Schreyögg, G., \& Koch, J. (2009). Organizational path dependence: opening the black Box. Academy of Management Review, 34(4), 689-709.

Szymanski, D. M., Bharadwaj, S. G., \& Varadarajan, P. R. (1993). Standardization versus adaptation of international marketing strategy: an empirical investigation. Journal of Marketing, 1-17. https://doi.org/10.2307/1252215

Tan, J., \& Peng, M. W. (2003). Organizational slack and firm performance during economic transitions: two studies from an emerging economy. Strategic Management Journal, 24(13), 1249-63. https://doi.org/10.1002/smj.351

Tan, Q., \& Sousa, C. M. (2013). International marketing standardization. Management international review, 53(5), 711-739. https://doi.org/10.1007/s11575-013-0172-5

Tan, Q., \& Sousa, C. M. P. (2011). Research on export pricing: still moving toward maturity. Journal of International Marketing, 19(3), 1-35. https://doi.org/10.1509/jimk.19.3.1

Teece, D. J., Pisano, G., \& Shuen, A. (1997). Dynamic capabilities and strategic management. Strategic Management Journal, 18(7), 509-33. https://doi.org/10.1002/(SICI)1097-0266(199708)18:7<509::AID-SMJ882>3.0.CO;2-Z

Theodosiou, M., \& Leonidou, L. C. (2003). Standardization versus adaptation of international marketing strategy: an integrative assessment of the empirical research. International Business Review, 12(2), 141-71. https://doi.org/10.1016/S0969-5931(02)00094-X

Thompson, J. D. (1967). Organizations in action. In Classics of organization theory, Shafritz JM, Ott, JS (eds). McGraw-Hill: New York.

Timmor, Y., \& Zif, J. (2005). A typology of marketing strategies for export. Journal of Global Marketing, 18(3/4), 3778. https://doi.org/10.1300/J042v18n03_03

Vorhies, D. W., \& Morgan, N. A. (2005). Benchmarking marketing capabilities for sustainable competitive advantage. Journal of Marketing, 69(1), 80-94. https://doi.org/10.1509/jmkg.69.1.80.55505

Voss, G. B., Sirdeshmukh, D., \& Voss, Z. G. (2008). The effects of slack resources and environmental threat on product exploration and exploitation. Academy of Management Journal, 51(1), 147-64. https://doi.org/10.5465/amj.2008.30767373

Vroom, V. H. (1964), Work and motivation. Wiley: New York.

Walker Jr., Orville C., \& Ruekert, R. W. (1987). Marketing's role in the implementation of business strategies: a critical review and conceptual framework. Journal of Marketing, 15-33.

Wind, Y. (1986). The myth of globalization. Journal of Consumer Marketing, 3(2), 23-26. https://doi.org/10.1108/eb008160

Yu, T., \& Cannella Jr., A. C. (2007).Rivalry between multinational enterprises: an event history approach. Academy of Management Journal, 50(3), 665-86. https://doi.org/10.5465/amj.2007.25527425 


\section{Appendix}

Measurement Scales

Formative Constructs

\begin{tabular}{ll}
\hline Abbreviation & Description \\
\hline Standardization- $t_{0}$ & List Price \\
Standard_1 & Discount Policies \\
Standard_2 & Product Quality \\
Standard_3 & Product Service \\
Standard_4 & \\
Price adaptive capability & Respond quickly to competitor changes \\
Adaptive_1 & Respond quickly to customer changes \\
Adaptive_4 & \\
Price formation capability & Knowledge of competitor's pricing tactics \\
Formation_2 & Monitoring competitor's prices and price changes \\
Formation_3 & Communication of price changes to customers \\
Formation_5 & Doing an effective job of pricing \\
Formation_6 & \\
\hline
\end{tabular}

\section{Reflective Constructs}

\begin{tabular}{ll}
\hline Abbreviation & \multicolumn{1}{c}{ Description } \\
\hline Slack resources after adaptation & Financial resources regarding $\ldots$ \\
Slack_1 & Market adaptation \\
Slack_2 & Future sales activities in market \\
Slack_3 & Personnel for future export activities \\
Slack_4 & Reaction on market changes \\
Price reaction- $t_{1}$ & List Price \\
Reaction_1 & Discount Policies \\
Reaction_2 & \\
\hline
\end{tabular}

\section{Copyrights}

Copyright for this article is retained by the author(s), with first publication rights granted to the journal.

This is an open-access article distributed under the terms and conditions of the Creative Commons Attribution license which permits unrestricted use, distribution, and reproduction in any medium, provided the original work is properly cited. 